\title{
Professionals In The Built Environment And The Incidence Of Building Collapse In Nigeria
}

\author{
Olumide Afolarin Adenuga \\ Faculty of Environmental Sciences, \\ University of Lagos, Lagos, Nigeria \\ oaadenuga@yahoo.com
}

DOI 10.5592/otmcj.2012.2.2

THE FAILURE OF BUILDINGS IS A NATIONAL PROBLEM, WHICH NOT ONLY RESULTS IN WASTE OF MATERIALS, FINANCIAL AND HUMAN RESOURCES BUT, SOMETIMES IN LOSS OF LIVES AND PROPERTIES. This occurrence has been a challenge to the professionals in the industry and as such necessitates the need for this study. The study examines the involvement of professionals in the incidence of buildings collapse in Lagos state. The research also identified and assessed the causes of building failure, evaluated the effects of such failures on construction professionals, the client, and the nation as a whole. In achieving these objectives, the study adopts a survey technique with a total of 65 questionnaires mainly for the professionals in the industry in which 50 were retrieved and used for the analysis. Random sampling technique was used in the selecting of the sample size. Data collected were analyzed using the frequency table, mean item score, one sample t test and paired sample t test. The study revealed that the building industry is full of quacks and inexperienced contractors. Their involvement in building construction has led to a lot of collapse in the past and at present. Poor management and leadership on the part of the Site Engineers and Builders have also contributed to many buildings failures. The analysis reveals that there are significant differences in the causes of building failure. The failures of buildings also have significant effects on the stakeholders. The study recommends that for all construction works being undertaken,

\section{Keywords}

Professionals, Built Environment, Collapse, Building Failure, and Nigeria such should be designed and supervised by qualified and registered Engineers and Builders. Also code of ethical conduct of building profession should be strongly enforced by the bodies concerned as to prevent ethical abuse by the professionals in the industry. 


\section{INTRODUCTION}

Naturally, shelter in form of building is amongst the three basic needs of life universally accepted and recognized as essential for life sustenance and survival. This single reason has made the construction industry one of the oldest and fastest growing industries both in terms of demands and sophistication over the years. However, it is the desire of every human being to live a life of comfort, security, physical and mental development without hints of possible mishaps of collapse or failure associated with there place of abode. It is therefore a social responsibility of the government to ensure that the wish of the people is achieved within a limited resources and constraints. Surprisingly, building construction industry in the past years has not witnessed the spate of building collapses and failures as it did in the recent past. The past few years in Nigeria witnessed the collapse of many buildings in various stages of completion, wherein, many lives were lost and properties worth millions of naira destroyed. These enunciated development calls for serious academic study to carry out an in-depth appraisal of the reasons for failures and collapsed of these buildings, the involvement of the professionals in the built environment and recommend the ways to minimize the increase in structural failure and collapsed of building structures

\section{Statement of Problems}

A nice edifice will surely attracts people attention and bring about a quest for who is the Architect? Otherwise when there is a failure, which probably results in a collapse, the reaction becomes; who is the Builder? The failures of building have resulted to waste of materials, financial and human resources, sometimes in loss of lives and properties. This affects the economy. Building failure affects the confidence of prospective and present clients in the building industry and as well it affects the integrity of the professionals in the industry.
Building failure can be considered as occurring when a building or building components can no longer be relied upon to fulfil its principal function. Building failures are common phenomena and is no longer news in Nigeria but, become problems when they result in loss of lives and properties. They occur during and after construction. Sometimes there is a single explanation for such mishap; more often there is a combination of reasons for such structural failure (lyagba and Odulami, 1989). Failures in buildings could be of two categories namely; cosmetic and structural failures (Ayininuuola, 2004). Cosmetic can be said to have occurred when something has been added or subtracted from the building thus affecting the structure's outlook. Structural on the other hand affects both the structural stability and outlook of the building. In Nigeria, building failures have been attributed to some causes namely design faults (50\%), faults on construction sites (40\%), product failure (10\%) (Oyewande, 1992). Faulty design, faulty execution of works and use of faulty materials are major causes of structural failures according to Hall (1984), on the other hand, (Akinpelu, 2002) classed environmental changes, natural and man made hazards, improper presentation and interpretation as major causes of structural failures. Other reasons behind building failures include lack of supervision, non-conformance with building regulations, poor construction techniques, and bad usage, amongst others. The research is appropriate at this time because of the effect of such failures; some of which are published. Sadly others are not, but they do affect the building construction industry by claiming lives, properties and also affect the economy especially when it leads to collapse.

\section{Aim of Study}

The aim of this research work is to assess the level of involvement of professionals in the built environment on the incidence of collapse of buildings and also evaluates the effects of such failures on construction professionals, the client, and the nation as a whole.

\section{Objectives of the Study}

In achieving the aim, the study set out the following objectives

1. To examine the causes of building failures.

2. To assess the level of involvement of building professionals in the causes of building failures.

3. To evaluate the effects of such failures on construction professionals, the client, and the nation as a whole.

\section{Research hypothesis}

None of the causes of building failure is more significant than the other.

\section{Literature Review}

Buildings are required to provide conducive and safe environment for various human activities. Naturally, one of the three basic needs of man is shelter, which is universally accepted and recognized as essential for life sustenance and survival (Adenuga, 1999). Several factors including greed, incompetence and corruption has affected the continuous existence of buildings during production and these have been associated with the recurring decimal of deadly collapse of buildings These practice are common among some construction professionals which include Contractors/ Builders who may use specified materials or going for sub-standard material in order to cut cost for his selfish interest (Chinwokwu, 2000).

According to lyagba (2005), doctors kill in unit while builders kill in tens. This statement has passed the test of time as a result of the increasing building collapse that has claimed many lives in our society. Buildings fail, not only because of how they are designed, but also because of how they were built and the management of a building during its life will also affect its life expectancy. $A$ lot of measures have been taken in the 
past to curb this menace. The subject of building failure came into existence during the Babylonian days. The code of Hammurabi (Circa 1950) is simple, and reproduced directly on the matter. It is interesting to note a part of it, as reproduced by (Mc Kaig, 1962) and reported in (lyagba, 2005). It reads: If a contractor builds a house for a man, the man shall give the contractor two shekels of silver per cent (a unit of weight) as reward. If a contractor builds a house for a man, but does not build it strong enough, and the house, which he built, collapses and causes the death of the owner of the house, then the contractor shall be put to death. If it causes the death of the son of the owner, then the son of the contractor shall be put to death. If the collapse destroys property, the contractor shall replace what has been destroyed, and if the house collapses, without any loss of life or property destruction, he shall rebuild the house at his own expense. In concise the message contains in the code is a tooth for tooth or an eye for an eye. During this period, the responsibility for building failures laid basically on the contractor. Today the situation is different due to the rapid advancement in construction, technology and revolutionary changes because of the experts that are now involved.

\section{Factors responsible for structural failures of collapsed buildings}

All buildings are prone to deterioration (i.e. wear and tear) and no structure can reasonably be expected to last forever. During construction works, a good quality control checks at periodic intervals with constant and adequate maintenance care will prolong their longevity. This proneness of buildings to depreciation (and degradation) is traceable to the materials, elements as well as composites used in constructing them. They exhibit different reactions when exposed to the environment, man-made conditions and the type of use they are subjected to. The geographical location and environmental conditions of the immediate environs of the building also have significant effect on materials specification. Other causes of structural defects according to Oloyede (1991), and Adenuga (1999) were attributed to the followings:

\section{(a) Socio-Economic habits of Nigerians}

It is often discovered that non-professionals design building and after the design by these quacks, for fear of paying appropriate fees to qualified people, the local planning authorities approve them. Again the right professionals are not appointed into the right positions in local authorities responsible for checking structural drawings.

\section{(b) Owner Constructor Syndrome}

The owner in a bid to save cost wants to build by himself using the so-called direct labour work force. The owner of the property purchase the materials by himself, buying cheap and inferior building materials without any idea of what type of materials should be bought for a particular part of a job. As reported by Warnang (1989) and Babatunde (1990), the failure of the five-storey building adjacent to 109, Western Avenue, Iponri, Lagos State that collapsed was partly attributed to the owner-contractor syndrome.

(c) Improper Supervision of Project during Construction

As reported by Akeju (1984) in his paper, Lessons from Recent Structural Failures; involvement of competent professionals to handle the planning and design of a project does not entirely guarantee its stability. The project competently created on paper must be faithfully and accurately reproduced on the site. A structure is said to be as good as its construction and not its design. An appropriate qualified professional must supervise every stage of the work.

\section{(d) Constructional Problems}

Subair (2008) reported that the use of poor materials and low standard of workmanship creep into construction as factor needed to lower the overall cost of construction. Some developers wrongly believe that by compromising slightly on materials quality, the overall effect on the structure will be little and the monetary gain will be large. This is wrong, the gain, money wise will be small and the danger to the structure will be enormous and destructive. Good materials in the hands of experienced artisans are the best ways of saving cost. Investigations into the collapsed building at Akinanmi Street, Ojuelegba as reported by Warnang (1989) and Babatunde (1990) revealed that the same foundation used for the first building that was demolished following a fire disaster, was the very one used for the new construction not minding the increased number of floors.

(e) Failure caused by Foundational Problems

Foundational failures are never due to a single cause, but there will always be one major cause. Olateju (1991) considered that foundational failure may be due to any or combination of:

- Absence of a proper investigation of the site or wrong interpretation of the results of such investigation

- Faulty design of the foundation

- Bad workmanship in the construction of the foundation

- Poor construction materials during the construction of the foundation due to financial constraints.

$\checkmark$ Insufficient provision in the design construction for exceptional natural phenomena such as thermal and biological conditions, rainfall and floods, greater than those hitherto recorded at the site.

\section{(f) Site Development Error}

This is often the case when construction is carried out with insufficient or non-existent geo-technical studies. Inadequate soil investigation before embarking on a new building work may result in structural failure and eventual collapsed. Studies have shown that steep slopes may be subjected to creep under heavy super imposed pressure. Sulphate in clay soil is deleterious to buried con- 
crete, iron and steel. High water table, which is seasonal, produces a lower soil bearing capacity than when the soil is dry, hence rendering construction inundated soils very expensive.

\section{(g) Design Errors}

These include errors in concept, assessment of loading, calculation errors, improper elemental assembles, inter-relationship errors, connection details errors, inability to visualize the mode of construction, maintainability, misuse of computer software and detailing errors. Design errors can result in a collapse but often times, failure due to design errors are easily traceable when not compounded by construction errors. Designers must take into consideration the mode of construction, in arriving at practicable designs.

\section{(h) Operational Errors}

These occur when alterations made to the structure are not taken into consideration during design. This usually occurs when there is an upward economic change in the value of the building location. A building, which might have been designed and constructed as residential, might be converted into a school or a supermarket requiring large free space or sometimes, more floors may be added thereby leading to overloading the existing foundation. Foundation and structural member's inadequacy are usually the causes of collapse in this regard. An example is the collapse of Sague School in Port-Harcourt claiming over 50 lives. (i) Inadequate Maintenance

Maintenance is a stitch in time that saves nine. Generally, much attention is not paid to maintenance and the government is the most guilty as observed by Adenuga (1999). The Sacred Heart Primary School building, which collapsed in River State, suffered a total neglect, which led to the crash. Also, the house that collapsed along Shetima Avenue, Kano State in July 1991 during heavy downpour was the Climax of the consequence of the neglect of the roof leakage.

Adenuga (1999) reported in his paper titled Building Maintenance in $\mathrm{Ni}$ - geria that maintenance of a structure that maintenance of a structure should start from the day the excavation is dug. For instance, if the foundation excavation shares before or after placement of concrete, it must be cleared and maintained because earth impurities impair the strength of concrete. Therefore, maintenance is a continuous exercise that ensures that defect is rectified as soon as they appear before further damage is done. This type of maintenance is called curative maintenance. An improved type of maintenance is the preventive maintenance, which of course, is more expensive. This involves checking of roof members of a building and replacing the bad ones at a specified or pre-determined period, even without any sign of leakage or sagging of the roof. The most expensive and elaborate type of maintenance is called planned maintenance. It is the most useful, most expensive but most cost effective over a long period especially in industrial or commercial buildings.

\section{Reasons for the present trend}

The reasons advanced for the present situation according to lyagba and Odunlami (1989) can be summarized as:

- Decline in site skills

- Lack of on-site trade training

Wide gap between designers and site operatives

- Building regulations not being applicable to certain buildings such as schools and public buildings

Difficulty to understand bye-laws and codes of practice

- Absence of maintenance manuals or lack of understanding or maintenance

$\checkmark$ Graft and corruption by some unscrupulous elements have given the construction industry an unenviable reputation and it is a known fact that Architects and Builders can offer favours to those who have the powers to award lucrative contracts.

- Structural failures are often determined after long investigations but usually after interest in the incident have waned and little publicity is given to the final report. As a result, recurrence of similar accidents and failures are still very common.

Non-recognition of the CORBON registered builders in the construction industry.

\section{Effects of Building Failures}

According to Olajumoke (2006), housing is more than mere shelter; it encompasses all ancillary service and community facilities, which are necessary for human well being. It is generally agreed that the most serious problems in the world today are in the so-called third world countries, which Nigeria is one of. The efforts made by the housing authority has yielded no fruit due to some reasons like poor implementation, party policies, illiteracy, inadequate finance, high cost of building materials, misconception etc. Failure definitely affects the building and the occupants. Generally the effects of building failure if not attended to through maintenance will automatically lead to building collapse and the results are summarized below:

Loss of lives: Experts say not less than 200 people die every year as a result of building collapse in Nigeria alone. (News watch 1987)).

Loss of money invested: The money invested on any building that collapses couldn't be recovered.

- Material wastage: Virtually all the materials used except the reinforcement cannot be recovered.

Prestige of the owner: The landowner's prestige is lost in the society and in any association he belongs to as people see him as an accomplice in the loss of lives and his property.

- Reputation of the contractor: It tarnishes the reputation of the contractors and Engineer.

- Loss of the buildings aesthetic values: The disintegration of a building results in the loss of its aesthetic values and may even constitute an eye sore in a place when such situations is the other of the day. 
Increase in the cost of maintenance: Maintenance cost on buildings due to dampness, cracking, and foundation failure could be avoided if the scaling off of parts, plaster and occurrence of creaks due to plants growth are checked effectively.

Leads to shortage of manpower: The occupants of such buildings are exposed to various diseases such as cholera, diarrhoea, malaria fever etc. These may constitute to a shortage of able bodies and minds, which may reflect in their jobs or businesses.

A great loss to the economy: The incessant building collapse is a threat to sustainable physical development. It is imperative to state that sustainable physical development implies that development activities in physical environment take into consideration crucial issues of continuity and sustenance. Tang (2008) stated that any development process that ignores sustainability would hardly make any positive enduring impact that could stand the test of time. When a building disintegrates gradually, it loses its strength and stability amongst other things and this leads to collapse, which will amount to the loss of huge sums of money invested in its construction. This would cause a great loss to the private owner and the Federal Government because; it will affect the economy indirectly. Due to the collapse of the buildings, occupants of such building are rendered homeless suddenly or run the risk of being injured or killed if buildings are not vacated on time.

\section{Remedies for Building Failures}

Remedies for building failures include amongst many others: Use of standard materials and workmanship; Involvement of professionals in construction; Site investigation and trial holes; Good design; Prompt and adequate maintenance; Good and adequate supervision.

\section{The Role of Professionals in} Averting Building Failures:

Ochshorn (2006), states that large scale structural failure is a nightmare that hunts the construction industry. The financial lost, the demolished reputation, and the loss of life that resulted from the collapsed of buildings have troubled the state of mind of every professional Builder, Engineer, Architect, the government and sometimes the owner. The professionals have a lot of stake in averting building failures in the country. So also three tier of government (Local, State and Federal) and government regulatory organs, such as the state Town and Regional Planning Authorities and Standard Organization of Nigeria (SON). While the professionals have the duty to practice their profession in accordance with lay down rules and procedures, government and regulatory organ have the task of enforcing certain laws and policies guiding design and construction of buildings and the existence of substandard material in our market today. Similarly, the professional bodies including the Architects, Builders, Engineers, Town Planners, Estate Surveyors, Quantity Surveyors and Estate Valuers have to come together periodically to discuss the problems of the industry. Both the government and the professionals owe it as a duty to teach the public how to embrace that which is good. According to Simire (2008), who spoke on the "impact of standards in the construction industry" charge the professionals to adopt standards in the sector, which will introduce sanity in the building industry, and enable Builders to source supply of materials from different sources without compromising the outcome of their product? Olateju (1991) opined that collapse of building is often preceded by excessive deflection leading to extension crack propagation. Inexperience or lack of technical know-how may not make these sounds reasonable to the untrained, which in his quest for capital gains may further aggravate the stress and strains un- til the collapse of building. The public at large should be informed about the fundamental requirement in building construction so as to be able to prevent them from patronising the untrained as to prevent the perpetual fatal building collapse in our society.

\section{Research Methodology}

The study adopted a survey research technique. The professionals working in different construction companies in Lagos State were chosen for the research, this is done to ensure adequate coverage of the population since larger percentage of the contractors operating in Nigeria operate from Lagos. The random sampling method was adopted for selecting this sample size using a wellstructured questionnaire, which was self-administered to the respondents.

The secondary data were sought through a careful search of different texts in the libraries, journals, different magazines with subject matters related to the study. The responses were analyzed using the method of simple proportions, percentages, and frequency tables, mean item score and standard deviation.

\section{Data Presentation and Analysis}

\begin{tabular}{|c|c|}
\hline Questionnaire Administered & 65 \\
\hline Questionnaire Received & 50 \\
\hline Response Rate & $77 \%$ \\
\hline
\end{tabular}

Table 1 Response Rate of Respondents

The table above shows that 65 questionnaires were administered and 50 were recovered in which response rate calculated resulted to $77 \%$. It is an indication of good response from the respondents.

Table 2: shows that $60 \%$ of the construction workers have less than 10 years of experience and $30 \%$ have 10 to 19 years experience, $6 \%$ have 20 to 29 years, while $4 \%$ have 30 to 39 years experience. This shows that $40 \%$ of the construction workers have more than 10 years of experience; meaning that they possess adequate years of working experience. 


\begin{tabular}{|c|c|c|}
\hline Working Experience & Frequency & Percentage \\
\hline Less than 10 years & 30 & 60.0 \\
\hline 10-19 years & 15 & 30.0 \\
\hline 20-29 year & 3 & 6.0 \\
\hline 30-39 years & 2 & 4.0 \\
\hline Total & 50 & 100.0 \\
\hline
\end{tabular}

Table 2 Working Experience of the Professionals in the Construction Industry

\begin{tabular}{|c|c|c|}
\hline Professions & Frequency & Percentage \\
\hline Architect & 5 & 10.0 \\
\hline Electrical Engineer & 5 & 10.0 \\
\hline Builder & 15 & 30.0 \\
\hline Mechanical Engineer & 4 & 8.0 \\
\hline Civil Engineer & 8 & 16.0 \\
\hline Quantity Surveying & 13 & 26.0 \\
\hline
\end{tabular}

Table 3 Profession of the Respondent

\begin{tabular}{|c|c|c|}
\hline Qualification & Frequency & Percentage \\
\hline OND or Equivalent & 1 & 2.0 \\
\hline PhD & 1 & 2.0 \\
\hline HND/B.Sc. & 44 & 88.0 \\
\hline Others & 4 & 8.0 \\
\hline Total & 50 & 100.0 \\
\hline
\end{tabular}

Table 4 Educational Qualification of the Respondent

\begin{tabular}{|c|c|c|}
\hline Professionals boies & Frequency & Percentage \\
\hline MNIA & 4 & 8.0 \\
\hline MNIQS & 9 & 18.0 \\
\hline MNIOB & 12 & 24.0 \\
\hline MNSE & 19 & 38.0 \\
\hline Others & 6 & 12.0 \\
\hline Total & 50 & 100.0 \\
\hline
\end{tabular}

Table 5 Professional Qualification of the Respondents

\begin{tabular}{|c|c|c|}
\hline Gender & Frequency & Percentage \\
\hline Male & 43 & 86.0 \\
\hline Female & 7 & 14.0 \\
\hline Total & 50 & 100.0 \\
\hline
\end{tabular}

Table 6 Gender of respondents

Table 3: shows that $10 \%$ were Architect, $10 \%$ were Electrical Engineer, $30 \%$ were Builder, $8 \%$ were Mechanical Engineer, $16 \%$ were Civil Engineer and $26 \%$ were Quantity Surveying. This shows that the all professionals in the built environment are well represented for the study.
Table 4: reveals that $2 \%$ of the respondents were OND holders, $2 \%$ were $\mathrm{PhD}$ holders and $88 \%$ were HND/ B.sc holders and others are $8 \%$. Thus the respondents are capable of providing the required information for the study, as most of the respondents are B.Sc holders.
Table 5: Shows that most of the respondents are Engineers with $38 \%$ of them being NSE members, $24 \%$ of the respondents are members of NIOB, $18 \%$ are members of NIQS and $8 \%$ are member of NIA. This reflects the professional skills of the respondents, which are found to be crucial to the practise of the profession.

Table 6: indicated that $86 \%$ of the respondents are male, while $14 \%$ of the respondents are female. This shows that the males are the pre-dominant professionals in the construction industry.

\section{Causes of Building Failure}

In order to assess the causes of building failure from the respondents, the following ratings were used. 1 -Strongly Disagree, 2 - Disagree, 3 - Neutral, 4- Agree, 5 -strongly Agree.

Table 7: represent the respondents ranking of the causes of building failures in the building selected for the study. The table shows that improper supervision, Poor materials and workmanship, Inadequate / Lack of maintenance, inadequate soil investigations are the main causes of building failure. Other causes are Lack of appropriate legislation against building failure, Patronage of quacks, Unethical practices of professionals, Construction problem, Engagement of unqualified builders / personnel, and Foundation Problems.

\section{Involvement of the}

\section{Professionals in the Causes of} Building Failure

In assessing the professional's involvement in the incidence of building failures the following rating were used. 1 - Strongly Disagree, 2 -Disagree, 3-Neutral, 4 -Agree, 5 - Strongly Agree

Table 8: represent the respondents ranking of the involvement of the Architects in building failure. The table shows that Failure of the Architect to inspect /supervise architectural work to meet quality control, failure to conform to building code of practice, failure to conform to the planning and zoning laws 


\begin{tabular}{|c|c|c|c|}
\hline Causes of failures & $\mathbf{N}$ & Mean & Rank \\
\hline Patronage of quacks & 50 & 4.54 & 1 \\
\hline Engagement of unqualified builders/personnel & 50 & 4.52 & 2 \\
\hline Inadequate soil investigation & 50 & 4.46 & 3 \\
\hline Improper supervision & 50 & 4.44 & 4 \\
\hline Poor materials and workmanship & 50 & 4.44 & 5 \\
\hline Foundation problems & 50 & 4.42 & 6 \\
\hline Non compliance to approved drawings & 50 & 4.20 & 7 \\
\hline Design errors & 50 & 4.16 & 8 \\
\hline Unethical practices of professionals & 50 & 4.14 & 9 \\
\hline Construction problems & 50 & 4.14 & 10 \\
\hline Inadequate/lack of maintenance & 50 & 4.06 & 11 \\
\hline Owner contractor syndrome & 50 & 3.94 & 12 \\
\hline Non possession of approved drawings & 50 & 3.92 & 13 \\
\hline Lack of appropriate legislation against building failure & 50 & 3.90 & 14 \\
\hline Inadequate funds & 50 & 3.84 & 15 \\
\hline Mis-use of building by occupants & 50 & 3.84 & 16 \\
\hline Unauthorized change of use & 50 & 3.66 & 17 \\
\hline Wide gap between designers and site operatives & 50 & 3.66 & 18 \\
\hline Site development errors & 50 & 3.66 & 19 \\
\hline Unclear specification and contract arrangement & 50 & 3.60 & 20 \\
\hline Inadequate knowledge about materials for construction & 50 & 3.58 & 21 \\
\hline Lack of on-site training & 50 & 3.52 & 22 \\
\hline Operator error & 50 & 3.34 & 23 \\
\hline
\end{tabular}

Table 7 Response to causes of building failures

\begin{tabular}{|c|c|c|c|}
\hline Involvement of professionals & $\mathbf{N}$ & Mean & Rank \\
\hline Failure to inspect /supervise architectural work to meet quality control & 50 & $4 \cdot 32$ & 1 \\
\hline Failure to conform to the building code of practice & 50 & 4.18 & 2 \\
\hline Failure to conform to the planning and zoning laws during design & 50 & 4.02 & 3 \\
\hline $\begin{array}{l}\text { Failure to prepare specification for all aspects of the work and consider } \\
\text { such item as cost efficiency in operation and maintenance }\end{array}$ & 50 & 4.02 & 4 \\
\hline Failure to convert design language to construction terms & 50 & 3.98 & 5 \\
\hline $\begin{array}{l}\text { Failure to ensure at all times that all elements of design are } \\
\text { properly coordinated and integrated within the master } \\
\text { programme requirement of the design and that design } \\
\text { fully take into account the codes of practice }\end{array}$ & 50 & 3.86 & 6 \\
\hline Improper planning & 50 & 3.74 & 7 \\
\hline Failure to document design concept to be used by various contractors & 50 & 4.70 & 8 \\
\hline
\end{tabular}

\section{Table 8 Contributions of the architect to building failure}




\begin{tabular}{|c|c|c|c|}
\hline Engineers involvement & $\mathbf{N}$ & Mean & Rank \\
\hline Failure to carry out proper soil test prior to construction operation & 50 & $4 \cdot 32$ & 1 \\
\hline $\begin{array}{l}\text { Failure to carry out concrete cube test to determine } \\
\text { the compressive strength of the concrete before use }\end{array}$ & 50 & 4.28 & 2 \\
\hline $\begin{array}{l}\text { Failure to provide site inspection of engineering works } \\
\text { and quality control checks }\end{array}$ & 50 & 4.16 & 3 \\
\hline Failure to inspect materials storage on site & 50 & 4.04 & 4 \\
\hline Failure to carry out the feasibility studies & 50 & 4.02 & 5 \\
\hline Failure to ensure that adequate access is provided to service installation & 50 & 4.00 & 6 \\
\hline $\begin{array}{l}\text { Failure to prepare preliminary engineering drawings } \\
\text { and equipment specification for the purpose of } \\
\text { planning approval and establishment of budget }\end{array}$ & 50 & 3.98 & 7 \\
\hline $\begin{array}{l}\text { Failure to consider the future maintenance and } \\
\text { replacement of building, fabrics, finishes, and services }\end{array}$ & 50 & 3.94 & 8 \\
\hline $\begin{array}{l}\text { Failure to prepare proposals regarding conceptual, } \\
\text { design, structural requirements, service and equipment }\end{array}$ & 50 & 3.88 & 9 \\
\hline $\begin{array}{l}\text { Failures to ensure adequate provision made for the most effective form of } \\
\text { lighting, electrical power, air conditioning, ventilation, drainage etc }\end{array}$ & 50 & 3.66 & 10 \\
\hline
\end{tabular}

\section{Table 9 Engineers Contributions to Building Failures}

during design and failure to prepare specification for all aspects of work the work and consider such items as cost efficiency in operation and maintenance are the major contributions to building failures by the Architect.

Table 9: represent the respondents ranking of the contributions of the Engineer in building failure. The table shows that Failure to carry out proper soil test prior to construction, failure to carry out concrete cube test to determine the comprehensive strength of the concrete before use, Failure to provide site inspection of engineering works and quality control checks, failure to inspect materials storage on site and failure to carry out feasibility studies are the major contributions to building failures by the Engineer.

Table 10: represents the respondents ranking of contributions of the Builder in building failure. The table shows that failure to assess the workmanship of craftsmen, Failure to suggest solution to technical problems, failure to ensure construction methodology and Failure to ensure maintainability analysis of production information are the major contributions of the Builders to building failure.
Table 11: represent the respondents ranking of the contributions of the Quantity surveyor to building failure. The table shows that Failure to study life cycle and cost in use, failure to identify client objectives and priorities, failure to advice on financial plans and procurement, failure to arrange for work to be measured, valued, and certified regularly and Failure to study feasibility of capital project are the main contributions of Quantity Surveyors to building failure.

Table 12: represents the respondents ranking of the contributions of the town planners to building failure. The table shows that failure to ensure building control measure, ethical abuse, failure to regulate land use by controlling type of occupancy, building heights, density, and activity of the population in specified area and failure to monitor building design during construction stage are the main contributions of the Town Planners to buildings failure.

\section{Effects of Building Failure}

In assessing the effects of building failure on the stakeholders from the respondents, the following ratings were used. 1- Strongly Disagree, 2- Disagree,
3 - Neutral, 4 - Agree, 5 - Strongly Agree.

Table 13: represents the respondents ranking of the effects of building failures on construction professional. The table shows that Loss of reputation, waste of resources time and labour; and loss of lives are the predominant effect of building failures on the professionals.

Table 14: represents the respondents ranking of the effects of building failures on the client. The table shows that waste of resources time and labour, loss investment, increase cost of maintenance, loss of strength of the building, degrading environment and loss of lives are the pre-dominant effects on the clients.

Table 15: represents the respondents ranking of the effects of building failures on the nation. The table shows that degrading environment, waste of resources time and labour, increments of sick citizens and loss of reputation were the predominant effects of building failures on the nation.

\section{Remedies to Building Failures}

In assessing the remedies to building failure from respondents, the following ratings were used. 


\begin{tabular}{|c|c|c|c|}
\hline Engineers involvement & $\mathbf{N}$ & Mean & Rank \\
\hline Failure to assess the workmanship of craftsmen & 50 & 4.18 & 1 \\
\hline Failure to suggest solution to technical problems & 50 & 4.16 & 2 \\
\hline Failure to ensure construction methodology & 50 & 4.12 & 3 \\
\hline Failure to ensure maintainability analysis of production information & 50 & 4.04 & 4 \\
\hline Failure to study production information & 50 & 3.98 & 5 \\
\hline Failure to provide Building production document & 50 & 3.88 & 6 \\
\hline Failure to write report on the builders documents & 50 & 3.76 & 7 \\
\hline Failure to manage the construction process & 50 & 3.70 & 8 \\
\hline Failure to be in charge of building and maintainability & 50 & 3.54 & 9 \\
\hline Failure to prepare programme of work & 50 & 3.54 & 10 \\
\hline
\end{tabular}

Table 10 Builders Contributions to Building Failure

\begin{tabular}{|c|c|c|c|}
\hline Quantity surveyors involvement & $\mathbf{N}$ & Mean & Rank \\
\hline Failure to study life cycle and cost in use & 50 & 3.92 & 1 \\
\hline Failure to identify client objective and priorities & 50 & 3.84 & 2 \\
\hline Failure to advise on financial plans and procurement & 50 & 3.78 & 3 \\
\hline $\begin{array}{l}\text { Failure to arrange for the work to be } \\
\text { measured, valued, and certified regularly }\end{array}$ & 50 & 3.76 & 4 \\
\hline Failure to study feasibility of capital project & 50 & 3.76 & 5 \\
\hline Failure to advise on capital investment & 50 & 3.74 & 6 \\
\hline $\begin{array}{l}\text { Failure to establish system of continuously monitoring } \\
\text { actual costs against the budget to provide the } \\
\text { control instrument required by the client }\end{array}$ & 50 & 3.72 & 7 \\
\hline Failure to monitor capital project & 50 & 3.66 & 8 \\
\hline Failure to prepare a budget for the project & 50 & 3.66 & 9 \\
\hline $\begin{array}{l}\text { Failure to establish procedures regarding the measuring of variation } \\
\text { and their costing and feedback into the overall cost budget position }\end{array}$ & 50 & 3.62 & 10 \\
\hline Failure to supply final cost to feedback information & 50 & 3.60 & 11 \\
\hline Failure to produce and update cash flow requirement & 50 & 3.44 & 12 \\
\hline
\end{tabular}

Table 11 Quantity Surveyors Contributions to Building Failure

\begin{tabular}{|c|c|c|c|}
\hline Town planners involvement & $\mathbf{N}$ & Mean & Rank \\
\hline Failure to ensure building control measures & 50 & 4.24 & 1 \\
\hline Ethical abuse & 50 & 4.22 & 2 \\
\hline $\begin{array}{l}\text { Failure to regulate land use by controlling type of occupancy, building } \\
\text { heights, density, and activity of the population in a specified area }\end{array}$ & 50 & 4.10 & 3 \\
\hline Failure to approve layout for building construction & 50 & 4.00 & 4 \\
\hline Failure to monitor building design during construction stage & 50 & 3.96 & 5 \\
\hline
\end{tabular}

\section{Table 12 Contributions of Town Planners to Building Failure}




\begin{tabular}{|c|c|c|c|}
\hline Quantity surveyors involvement & $\mathbf{N}$ & Mean & Rank \\
\hline Loss of reputation & 50 & $4 \cdot 54$ & 1 \\
\hline Waste of resources time and labour & 50 & 4.22 & 2 \\
\hline Loss of lives & 50 & 4.16 & 3 \\
\hline Loss of strength of the building & 50 & 4.06 & 4 \\
\hline Degrading Environment & 50 & 3.98 & 5 \\
\hline Loss of Aesthetic value & 50 & $3 \cdot 90$ & 6 \\
\hline Shortage of manpower & 50 & $3 \cdot 90$ & 7 \\
\hline Increase cost of maintenance & 50 & 3.80 & 8 \\
\hline Loss of investment & 50 & 3.80 & 9 \\
\hline Increment of sick citizens & 50 & 3.60 & 10 \\
\hline
\end{tabular}

Table 13 Effect of building failure on the professionals

\begin{tabular}{|c|c|c|c|}
\hline Effects of failures & N & Mean & Rank \\
\hline Waste of resources time and labour & 50 & 4.64 & 2 \\
\hline Loss of investment & 50 & 4.34 & 3 \\
\hline Increase cost of maintenance & 50 & 4.28 & 4 \\
\hline Loss of strength of the building & 50 & 4.14 & 5 \\
\hline Degrading Enviroment & 50 & 4.12 & 6 \\
\hline Loss of lives & 50 & 4.08 & 7 \\
\hline Loss of Aesthetic value & 50 & 4.00 & 8 \\
\hline Loss of reputation & 50 & 3.78 & 9 \\
\hline Increment of sick citizens & 50 & 3.68 & 10 \\
\hline
\end{tabular}

Table 14 Effects of Building Failure on the Clients

1 - Strongly Disagree, 2 -Disagree, 3-Neutral, 4-Agree, 5 -Strongly Agree

Table 16: represents the respondents ranking of the remedies to building failure. The table shows that good and adequate supervision, use of standard materials, involvement of professional to ensure good and adequate supervision, soil investigation discipline of professional if proven that they are involved in misconducts, promulgation of appropriate legislation against building failure, proper check of detailing by builder and designer and compliance to approved drawings are the predominant remedies to building failures.

\section{Hypothesis Testing}

Hypothesis: None of the causes of building failure is more significant than the other.

The result for one sample $t$ test is presented in the table 17.

The value of $t$ tabulated at the significant level of 0.05 is 2.021 and comparing the value with the various $t$ calculated, it was observed that the $t$ tabulated is lesser to the $t$ calculated. As such the null hypothesis is rejected and the alternative hypothesis, which says causes of building failure, is more significant than the other is accepted.

\section{Summary of Findings}

The study revealed that:

More men are found to be dominating the construction industry.

The patronage of quacks, engagement of unqualified builders / personnel, inadequate soil investigation, improper supervision, improper supervision and lack of appropriate legislation against building failures are the main causes of building failure.

Degrading environment and waste of resources time and labour are the major effects of building failures.

Building professionals are found to be contributing to building failures especially when they fail to perform the roles as stated in their professionals practise. 


\begin{tabular}{|c|l|l|l|}
\hline Effects of failures & N & Mean & Rank \\
\hline Degrading Environment & 50 & 4.40 & 1 \\
\hline Waste of resources time and labour & 50 & 4.38 & 2 \\
\hline Increment of sick citizens & 50 & 4.30 & 3 \\
\hline Loss of reputation & 50 & 4.26 & 5 \\
\hline Shortage of manpower & 50 & 4.16 & 6 \\
\hline Increase cost of maintenance & 50 & 4.04 & 7 \\
\hline Loss of strength of the building & 50 & 3.94 & 8 \\
\hline Loss of investment & 50 & 3.92 & 9 \\
\hline Loss of Aesthetic value & 50 & 3.90 & 1.76 \\
\hline
\end{tabular}

Table 15 Effects of Building Failure on the Nation

\begin{tabular}{|c|c|c|c|}
\hline Remedies of failures & $\mathbf{N}$ & Mean & Rank \\
\hline Good and adequate supervision & 50 & 4.62 & 1 \\
\hline Use of standard materials & 50 & 4.58 & 2 \\
\hline $\begin{array}{l}\text { Involvement of professional builders } \\
\text { in the construction process }\end{array}$ & 50 & 4.56 & 3 \\
\hline Soil Investigation & 50 & 4.50 & 4 \\
\hline Discipline of professionals, if proven that they are involved in failures & 50 & 4.46 & 5 \\
\hline Promulgation of appropriate legislation against building failure & 50 & 4.44 & 6 \\
\hline Proper check of detailing by builder and designer & 50 & 4.42 & 7 \\
\hline Compliance to approved drawings & 50 & 4.42 & 8 \\
\hline Provision of a detailed design & 50 & 4.38 & 9 \\
\hline $\begin{array}{l}\text { Involvement of professional Builders in } \\
\text { the composition if building regulation }\end{array}$ & 50 & 4.38 & 10 \\
\hline Adequate and firm inspections & 50 & 4.36 & 11 \\
\hline Strict compliance to data available and geotechnical properties of the soil & 50 & 4.36 & 12 \\
\hline Prompt and necessary measure towards deterioration \& defect & 50 & 4.30 & 13 \\
\hline Proper site investigation and development & 50 & 4.30 & 14 \\
\hline Enforcement of Insurance of buildings against failures & 50 & 4.18 & 15 \\
\hline Correct use and installation of fittings & 50 & 4.16 & 16 \\
\hline Adequate and planned maintenance & 50 & 4.14 & 17 \\
\hline Education of the occupiers of the building & 50 & 4.06 & 18 \\
\hline Publicity of the consequences of illegal buildings & 50 & 4.02 & 19 \\
\hline
\end{tabular}

\section{Table 16 Remedies to building failure by the respondents}

Clients need to be educated on the need to snub quacks; it is a principal crime for non-professionals to handle any construction project.
Building professionals should be prepared to flush out quacks without delay.

An appropriate legislation should be promulgated against building failure.
The involvement of construction professionals in the design and construction of buildings is the most effective way of reducing building failures. 


\begin{tabular}{|c|c|c|c|c|c|c|}
\hline \multirow[t]{2}{*}{ Causes of building failure } & \multirow[t]{2}{*}{$\mathbf{t}$} & \multirow[t]{2}{*}{ df } & \multirow[t]{2}{*}{$\begin{array}{c}\text { Sig. } \\
\text { (2-tailed) }\end{array}$} & \multirow{2}{*}{$\begin{array}{c}\text { Mean } \\
\text { Difference }\end{array}$} & \multicolumn{2}{|c|}{$\begin{array}{l}95 \% \text { Confidence } \\
\text { Interval of the } \\
\text { Difference }\end{array}$} \\
\hline & & & & & Lower & Upper \\
\hline Improper supervision & 58.076 & 49 & .000 & $4 \cdot 440$ & 4.29 & $4 \cdot 59$ \\
\hline Poor materials and workmanship & 48.753 & 49 & .000 & $4 \cdot 440$ & 4.26 & 4.62 \\
\hline Inadequate soil investigation & 46.623 & 49 & .000 & 4.460 & 4.27 & 4.65 \\
\hline Inadequate/lack of maintenance & $29 \cdot 369$ & 49 & .000 & 4.060 & 3.78 & $4 \cdot 34$ \\
\hline Owner contractor syndrome & 33.049 & 49 & .000 & 3.940 & 3.70 & 4.18 \\
\hline Design errors & $35 \cdot 997$ & 49 & .000 & 4.160 & 3.93 & $4 \cdot 39$ \\
\hline Patronage of quacks & 42.153 & 49 & .000 & 4.540 & $4 \cdot 32$ & 4.76 \\
\hline Foundation problems & 35.407 & 49 & .000 & $4 \cdot 420$ & 4.17 & 4.67 \\
\hline Construction problems & 37.401 & 49 & .000 & 4.140 & 3.92 & $4 \cdot 36$ \\
\hline Non possession of approved drawings & 28.708 & 49 & .000 & 3.920 & 3.65 & 4.19 \\
\hline Non compliance to approved drawings & 39.287 & 49 & .000 & 4.200 & 3.99 & $4 \cdot 41$ \\
\hline Engagement of unqualified builders/personnel & 58.795 & 49 & .000 & $4 \cdot 520$ & $4 \cdot 37$ & 4.67 \\
\hline Site development errors & 27.556 & 49 & .000 & 3.660 & $3 \cdot 39$ & 3.93 \\
\hline Operator error & 25.147 & 49 & .000 & $3 \cdot 340$ & 3.07 & 3.61 \\
\hline Lack of appropriate legislation against building failure & 26.149 & 49 & .000 & 3.900 & 3.60 & 4.20 \\
\hline Mis-use of building by occupants & 29.080 & 49 & .000 & 3.840 & $3 \cdot 57$ & 4.11 \\
\hline Unethical practices of professionals & 28.974 & 49 & .000 & 4.140 & 3.85 & $4 \cdot 43$ \\
\hline Wide gap between designers and site operatives & 29.694 & 49 & .000 & 3.660 & $3 \cdot 41$ & $3 \cdot 91$ \\
\hline Lack of on-site training & $24 \cdot 523$ & 49 & .000 & $3 \cdot 520$ & 3.23 & 3.81 \\
\hline Inadequate knowledge about materials for construction & 26.076 & 49 & .000 & $3 \cdot 580$ & $3 \cdot 30$ & 3.86 \\
\hline Unauthorized change of use & 26.940 & 49 & .000 & 3.660 & 3.39 & 3.93 \\
\hline Unclear specification and contract arrangement & 21.609 & 49 & .000 & 3.600 & 3.27 & 3.93 \\
\hline Inadequate funds & 29.786 & 49 & .000 & 3.840 & 3.58 & 4.10 \\
\hline
\end{tabular}

Table 17 One Sample T Test for Significant Level of Causes of Building Failures

Other major ways of reducing building failures are the use of standard materials, adequate supervision, and adequate and regular maintenance.

The test of the hypotheses is revealed that the causes of building are more significant than the other.

- The test of another hypothesis also revealed that building failure has significant effect on the stakeholders (i.e. client and construction professionals).

\section{Conclusions}

From the study carried out, it is evident that building failure is not caused by a single factor but multiple factors, most of which are human factors. The building industry today is full of quacks and inexperienced contractors, who enrich their purses and consequently produce substandard buildings, which is hazardous to the owners and occupants. The major reason for building failure stems from the patronage of quacks, which invariably results in inadequate design and poor supervision. This has continued for ages despite the calls made over the years for the patronage of building professionals and the integration of design and construction process.
Furthermore, the use of inferior building materials, which does not conform to the British standard and specification, is one of the factors affecting the construction of sound buildings. Most clients construct their buildings using just one quack, who serves as Architect, Builder, Quantity surveyor and Engineer. Poor management and leadership on the part of site Engineers and Builders has also caused a lot of building failures. Lastly, there is the absence of an effective planning approval authority, also where approval is obtained; it is not adhered to. 


\section{Recommendations}

Based on the findings, it is pertinent to make recommendations on ways to reduce, if not eliminate the causes of building failures and to prevent the reoccurrence of the ugly situations that follows such failures such as social and economic results. The recommendations are as follows:

- A qualified and professional designer must always be allowed to undertake designs of buildings.

- Only professional and qualified builders, engineers and architects should take control of the supervision of buildings.

Building contractors should be monitored to guarantee the use of high quality materials.

- The local planning authorities in charge of approving building plans should be properly organized, in order to enforce all building laws and regulations and establish a building control unit.

Registered builders should be employed by local planning authorities to enforce the necessary building regulations.

- Prior to any design work, adequate investigation must be carried out as to enable the design of a suitable foundation..

- Cost of building materials, should be reduced by the government, in order to reduce the temptation to use substandard materials.

All materials used in the building industry should strictly comply with the British standard. The authorities of the Nigerian Institute of Building should enforce this.

- Appropriate construction methods should be adopted.

- A better maintenance culture should be developed.

- Code of ethical conduct of building profession should be strongly enforced by the bodies concern as to prevent ethical abuse by the professionals in the industry.

\section{References}

Adenuga O.A (1999) Building Maintenance in Nigeria: Structural Deterioration, ignition and Diagnosis of causes and Remedies. Shelter watch, Vol. 001.No June-July pp 5-25.

Akeju, T.A. (1984): “Lessons from recent structural failures”. The Nigerian Engineer. 1984. Vol. 19. No. 2.

Akinpelu, J.A. (2002): The need for code of conduct, building regulations and byaws for the building industry in Nigeria. The Professional Builder,

Nigeria Institute of Building, pp 11-14

Ayinuola, G.M and Olalusi, 0.0, (2004),

"Assessment of building failure in Nigeria" African journal of science and technology, science and engineering series, Vol. 5, No 1

Chinwokwu, (2000). The role of professionals in averting building collapse, the Nigerian institute of building publication, may 3 rd and 4th, pg 12-27.

Hall, G.T. (1984): Revision Notes on Building Maintenance and Adaptation,

Butterworths and Co., England.

lyagba, R. O. A. (2005): The menace of sick buildings - a challenge to all for its prevention and treatment.

An Inaugural lecture delivered at University of Lagos, Lagos.

lyagba, R (1989): “Lesson for the construction Industry from Building Disaster and Failures" (1989).

Mc kaig, T. H. (1962): Building Failures Case Studies in Construction and Design (1962).

Ochshorn, J. (2006), “Designing building Failures" An essay presented at the Building Technology Educators Symposium, University of Maryland, College Park.

Olajumoke, A.M., Oke, I .A., Fajobi, A.B. and Ogedengbe, M.O, (2006), “Technical Assessment and Remediation of a failed Building in Osun State of Nigeria” Journal of Applied Science Research, 2(8): 462-465,2006.

Olateju, B. O. (1991): Effective Contract Management in the Construction Industry, Lagos, (1991).

Oloyede, G. (1991): “Structural Failures - Causes, lessons and responsibilities of the Structural Engineers" (1991).

Oyewande, B. (1992): A research for quality in the construction industry. Builder's Magazine, June/July Ed., Lagos.
Simire, M. (2008), "Why buildings experience structural failure" Daily Independent (Friday 18th January 2008)

Subair, G. (2008) “Building!” Nigerian tribune, Business and Economy (Jan 2008 edition)

Tang Lee (2008) “Building Failures” Macmillan Press Limited, London England.

Wannag, C. Y (1989): Reducing the incidence of Building collapse in the Nigerian Construction Industry May, 1989. 